\title{
Article \\ Effects of Si/Al Ratios on the Bulk-Type Zeolite Formation Using Synthetic Metakaolin-Based Geopolymer with Designated Composition
}

\author{
Guoru Ma ${ }^{1}$, Chengying Bai ${ }^{2, *} \mathbb{C}$, Meirong Wang ${ }^{3, *}$ and Peigang $\mathrm{He}^{4}$ \\ 1 Beijing Building Materials Testing Academy Co., Ltd., Beijing 100024, China; guoruma@163.com or \\ maguoru@bmtbj.cn \\ 2 Key Laboratory of Superlight Materials and Surface Technology, Ministry of Education, College of Materials \\ Science and Chemical Engineering, Harbin Engineering University, Harbin 150001, China \\ 3 Harbin Institute of Technology, School of Materials Science and Engineering, Weihai 264209, China \\ 4 Harbin Institute of Technology, Institute for Advanced Ceramics, School of Materials Science and \\ Engineering, Harbin 150001, China; peiganghe@hit.edu.cn \\ * Correspondence: chengyingbai@163.com or chengyingbai@hrbeu.edu.cn (C.B.);wmr21c@163.com or \\ wmr21c@hit.edu.cn (M.W.); Tel.: +86-0451-8256-8337 (C.B.)
}

Citation: Ma, G.; Bai, C.; Wang, M.; $\mathrm{He}$ P. Effects of $\mathrm{Si} / \mathrm{Al}$ Ratios on the Bulk-Type Zeolite Formation Using Synthetic Metakaolin-Based Geopolymer with Designated Composition. Crystals 2021, 11, 1310. https://doi.org/10.3390/ cryst 11111310

Academic Editor: Shujun Zhang

Received: 11 October 2021

Accepted: 22 October 2021

Published: 27 October 2021

Publisher's Note: MDPI stays neutral with regard to jurisdictional claims in published maps and institutional affiliations.

Copyright: (c) 2021 by the authors. Licensee MDPI, Basel, Switzerland. This article is an open access article distributed under the terms and conditions of the Creative Commons Attribution (CC BY) license (https:// creativecommons.org/licenses/by/ $4.0 /)$.

\begin{abstract}
In this paper, synthetic metakaolin with fixed composition $\left(\mathrm{Al}_{2} \mathrm{O}_{3} \cdot 2 \mathrm{SiO}_{2}\right)$ was produced by a simple chemosynthetic route. The chemosynthetic metakaolin can eliminate the influence of impurities in metakaolin from natural kaolin minerals. The synthetic metakaolin together with $\mathrm{NaOH}$ and $\mathrm{SiO}_{2}$-sol were used to prepare Na-based geopolymer precursors with various molar ratios of $\mathrm{Si} / \mathrm{Al}$. The molar ratios of $\mathrm{Si} / \mathrm{Al}$ from 1 to 2 were tailored by adding different contents of $\mathrm{SiO}_{2}$-sol. Zeolite/geopolymer composites or monolith-type zeolite were successfully fabricated from synthetic metakaolin-based geopolymer through a hydrothermal process. The effects of $\mathrm{Si} / \mathrm{Al}$ ratios on the phase composition and microstructure of the produced zeolite/geopolymer composites or zeolites were studied. The results proved that the composition of synthetic metakaolin and geopolymer precursors can be facilely tuned, and the monolithic geopolymer precursors can be mostly, or even totally, transformed into zeolite after hydrothermal treatment.
\end{abstract}

Keywords: geopolymer; zeolite; hydrothermal treatment; metakaolin; geopolymer composites

\section{Introduction}

Porous geopolymers have attracted a lot of attention, due to their low price, extensive sources of raw materials, excellent mechanical properties, high thermal and chemical stability, easy fabrication, consolidation/setting at room or low temperature as well as offering a wider range of applications than dense geopolymers [1,2]. Recently, a series of synthesis and preparation pathways, including direct foaming [3], embedding lightweight fillers or embedding porous fillers [4], the replica method [5], reactive emulsion templating [6], immersion and impregnation [7], additive manufacturing [8], freeze-casting [9], etc., as well as the combination of these [10] were explored to obtain porous geopolymer and geopolymer-matrix composites with high porosity or/and a tunable microstructure. The synthesis and preparation pathways were inspired and learned from other porous materials, such as ceramics [11,12], polymers [13,14], metals [15], concretes [16], etc. The fabrication routes, properties and corresponding applications of porous geopolymer-matrix composites were recently reviewed [17]. Various reinforcing and/or functional agents (e.g., zeolite, active carbon, $\mathrm{SiC}$, hollow spheres, graphene, chitosan, and resin) were added into the geopolymer matrix to further enhance or optimize the performance, or to endow new functions [17]. In these composite materials, there are more and more research studies about zeolite/geopolymer composites, due to the advantageous combination of zeolite (functional agent with high surface area, porosity, and good adsorption performance) and 
geopolymers (matrix with high mechanical strength and good chemical stability) $[17,18]$. Zeolite/geopolymer composites can be formed mainly by three routes $[17,18]$ : zeolite as a second phase directly added into the geopolymer slurry $[19,20]$; zeolite phase can be formed together with the geopolymerization process [21,22]; geopolymer is partially or completely transformed into zeolite after hydrothermal treatment [23,24].

Zeolites have garnered huge attention, due to their highly attractive properties, including facilely controllable chemical compositions, high specific surface areas and adsorption capabilities, excellent thermal and chemical stabilities, ordered networks of micropores (typically $0.25-1.5 \mathrm{~nm}$ ), their well-defined pore sizes and pore structure along with good shape selectivity, etc. [25-29]. They are widely applied in agriculture and animal husbandry [30-33], building $[19,34]$, water purification $[28,35,36]$, synthesis and catalysis $[27,37-39]$ and other fields [40]. Zeolites can be formed in nature, also known as zeolite minerals, or be synthesized artificially [41], and more than 200 types of framework were reported [40]. The history of zeolite synthesis can be traced back to the 1950s, with various synthesis routes, including hydrothermal synthesis, molten salt route, microwave synthesis, fusion route, alkali activation route, synthesis by dialysis and others [29,36,38,40,41]. Simultaneously, geopolymers can be prepared by mixing amorphous aluminosilicate minerals under strong alkaline solutions. The geopolymerization reaction process is similar to that of zeolite, and zeolite phase can be generated with the geopolymerization process under suitable conditions [21,22]. A more common route was reported by partially or completely transforming geopolymer gels/precursors into zeolites after hydrothermal treatment [17,18,23].

Possessing porous structure with or without a second phase for one or more functional purposes is regarded as an efficient route for high added-value materials [39,42,43]. Metakaolin (MK) is one of the most common aluminosilicate mineral materials for porous geopolymer preparation [1]. Compared with natural metakaolin (N-MK), synthetic metakaolin (S-MK) through chemical reaction is simple in composition and thus, provides more precise chemical composition of the final geopolymer materials [44-46]. To assess the impact of the ratio of $\mathrm{Si} / \mathrm{Al}$ on the zeolite hydrothermal transformation and to overcome the influence by impure raw materials, an amorphous $\mathrm{Al}_{2} \mathrm{O}_{3}-\mathrm{SiO}_{2}$ powder (S-MK) is firstly synthesized with designated chemical compositions, according to a polymeric steric entrapment precursor route [47-49]. Previous works showed that the $\mathrm{Si} / \mathrm{Al}$ ratio or $\mathrm{SiO}_{2} / \mathrm{Al}_{2} \mathrm{O}_{3}$ had a significant effect for zeolite formation [50-52]. It showed that neither a too high nor too low molar ratio for $\mathrm{Si} / \mathrm{Al}$ or $\mathrm{SiO}_{2} / \mathrm{Al}_{2} \mathrm{O}_{3}$ was detrimental for the degree of crystallization after hydrothermal treatment $[51,52]$. The intensity of the zeolite phase decreased or even vanished when the $\mathrm{Si} / \mathrm{Al}$ ratio increased by the formation of zeolite during the geopolymerization [50]. Previous works presented that the composition ( $\mathrm{Si} / \mathrm{Al}$ molar ratio [53-55], $\mathrm{H}_{2} \mathrm{O} / \mathrm{Na}_{2} \mathrm{O}$ ratio [56,57]), curing regime [57,58] of geopolymer precursor, and hydrothermal conditions of systems (alkalinity, hydrothermal time, and hydrothermal temperature) $[51,52,57,59]$ observably influenced the zeolite formation and morphology of the synthesized zeolites as well. To eliminate the influence of other factors, geopolymer precursor with pure amorphous $\mathrm{Al}_{2} \mathrm{O}_{3}-2 \mathrm{SiO}_{2}$ powder (S-MK) was firstly obtained by the polymeric steric entrapment precursor route, and the $\mathrm{Si} / \mathrm{Al}$ molar ratio on the zeolite transformation using the hydrothermal process was investigated.

In this paper, MK-based zeolite/geopolymer composites using S-MK were produced by a hydrothermal process. The properties of S-MK were well studied, and the effect of the $\mathrm{Si} / \mathrm{Al}$ molar ratios on the cellular morphology, and phase evolutions of the obtained zeolite and zeolite/geopolymer composites was investigated.

\section{Materials and Methods}

\subsection{Raw Materials and Sample Preparation}

The preparation process (Figure 1) for synthetic metakaolin (S-MK) by organic steric entrapment method is as follows [49]: 


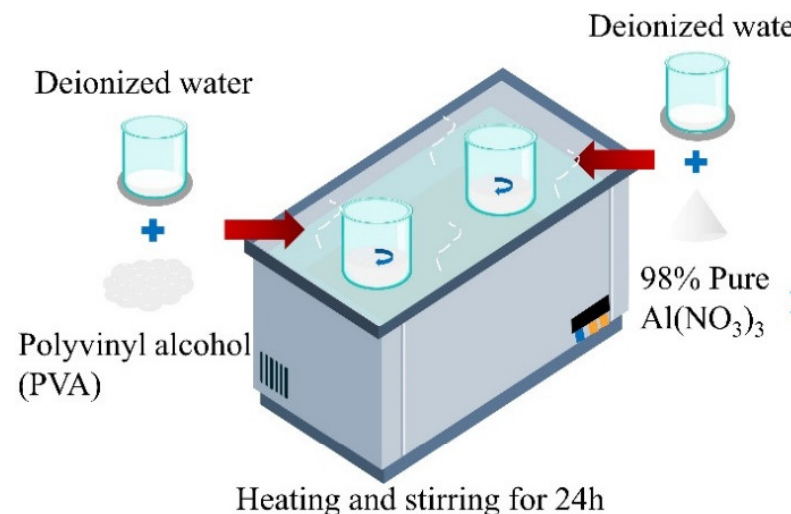

(1)

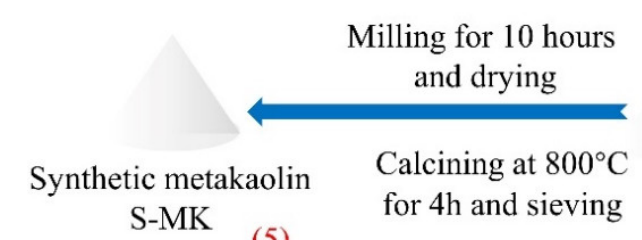

(5)

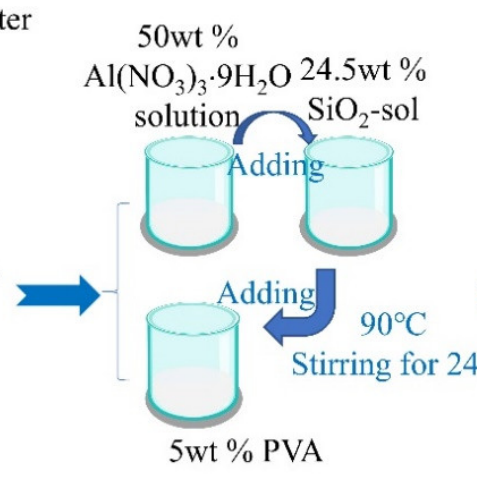

(2)

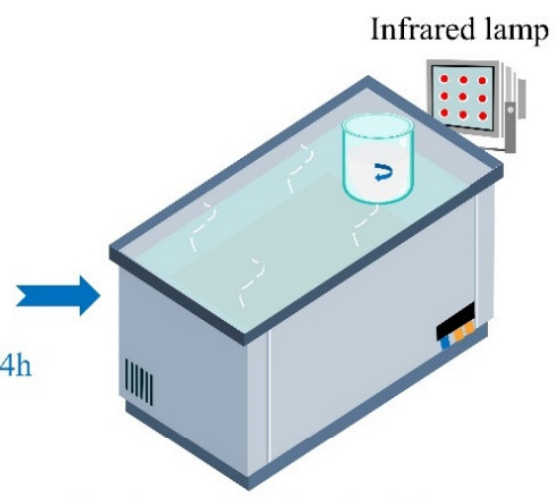

Heating and stirring for $12 \mathrm{~h}$

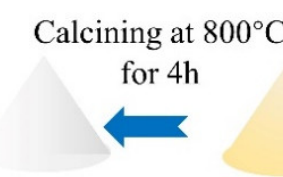

(4)
Drying for $12 \mathrm{~h}$

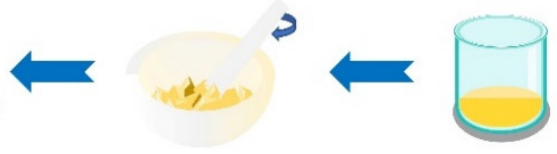

Alumina mortar

(3)

Figure 1. The schematic diagram of fabrication process for the synthetic metakaolin, using the polymeric steric entrapment precursor route.

(1) The $5 \mathrm{wt} \%$ polyvinyl alcohol (PVA) solution and $50 \mathrm{wt} \% \mathrm{Al}\left(\mathrm{NO}_{3}\right)_{3} 9 \mathrm{H}_{2} \mathrm{O}$ solution with deionized water were respectively prepared by stirring for $24 \mathrm{~h}$ in a water bath.

(2) The $50 \mathrm{wt} \% \mathrm{Al}\left(\mathrm{NO}_{3}\right)_{3} \cdot 9 \mathrm{H}_{2} \mathrm{O}$ solution was added into $24.5 \mathrm{wt} \% \mathrm{SiO}_{2}$-sol (Xiagang Reagent Company, Jiangsu, China) and stirred for $2 \mathrm{~h}$, and then $5 \mathrm{wt} \%$ PVA solution was added into the mixed solution. The three mixed solution was obtained with the composition of $\mathrm{Al}_{2} \mathrm{O}_{3} \cdot 2 \mathrm{SiO}_{2} \cdot 3.5 \mathrm{PVA}$ (mole ratio).

(3) The prepared mixed solution was irradiated under an infrared lamp while heating and stirring for $12 \mathrm{~h}$. After drying for $12 \mathrm{~h}$, the mixed solution turned into an egg-yellow mixture, and the mixture was then ground into powder with an alumina mortar.

(4) The obtained powder was calcined at $800{ }^{\circ} \mathrm{C}$ for $4 \mathrm{~h}$, and the heating rate was $5^{\circ} / \mathrm{min}$. The color of the powder became white after sintering. The chemical composition of the ideal powder is $\mathrm{Al}_{2} \mathrm{O}_{3} \cdot 2 \mathrm{SiO}_{2}$.

(5) The sintered powder was ball milled for $10 \mathrm{~h}$, using anhydrous ethanol as the medium after which the solution was dried and finally calcined at $800{ }^{\circ} \mathrm{C}$ for $4 \mathrm{~h}$ to remove all the organic matter in order to obtain metakaolin. Synthetic metakaolin (S-MK) was obtained after screening through a 100-mesh sieve; the composition of the S-MK is showed in Table 1.

Table 1. Chemical composition (wt\%) of the N-MK and S-MK and $\mathrm{SiO}_{2}$-sol.

\begin{tabular}{ccccccc}
\hline Label & $\mathrm{SiO}_{2}$ & $\mathrm{Al}_{2} \mathrm{O}_{3}$ & $\mathrm{Fe}_{2} \mathrm{O}_{3}$ & $\mathrm{MgO}$ & $\mathrm{CaO}$ & $\mathrm{TiO}_{2}$ \\
\hline N-MK & 51.91 & 40.40 & 0.92 & 0.06 & 0.11 & 0.76 \\
S-MK & 54.05 & 45.95 & - & - & - & - \\
\hline
\end{tabular}

For comparison, natural metakaolin (N-MK) was obtained by calcined kaolin (Fengxian Reagent Company, Shanghai, China) at $800{ }^{\circ} \mathrm{C}$; the composition of N-MK was investigated [23] and is shown in Table 1. A pellucid activating solution was produced by mixing $\mathrm{NaOH}$ particles (96\% purity, Shanghai Aladdin Biochemical Technology Co., Ltd., Shanghai, China), distilled water, and the $\mathrm{SiO}_{2}$-sol with a $40.0 \mathrm{wt} \% \mathrm{SiO}_{2}$ content, using magnetic stirring apparatus for $48 \mathrm{~h}$. Geopolymer slurries were simply obtained through successively adding the MK into the activation solution under mechanical mixing and 
ultrasonic processing for $45 \mathrm{~min}$. Finally, the slurries with various content of $\mathrm{SiO}_{2}$-sol or without $\mathrm{SiO}_{2}$-sol were casted into molds and cured in an electric heating drying oven at $60^{\circ} \mathrm{C}$ for 7 days.

The obtained monolithic geopolymer samples were transformed into zeolite under hydrothermal treatment. Here, the hydrothermal transformation was performed, using a $100 \mathrm{~mL}$ Teflon-lined hydrothermal reactor at $160^{\circ} \mathrm{C}$ for $6 \mathrm{~h}$, and a $1.0 \mathrm{~mol} / \mathrm{L} \mathrm{NaOH}$ solution was used as the medium for the hydrothermal process. After the drying step at $60{ }^{\circ} \mathrm{C}$ for at least 2 days, the specimens were evaluated. Table 2 lists the mixture formulations for bulk-type specimens with a designated composition. The theoretical chemical form of $\mathrm{NaA}$ zeolite and analcime are $\left(\mathrm{Na}_{96}\left[\left(\mathrm{AlO}_{2}\right)_{96}\left(\mathrm{SiO}_{2}\right)_{96}\right] \cdot 216 \mathrm{H}_{2} \mathrm{O}\right.$ [44] and $\mathrm{NaAlSi}_{2} \mathrm{O}_{6} \cdot \mathrm{H}_{2} \mathrm{O}[18,33]$. As can be seen, samples with a different $\mathrm{Si} / \mathrm{Al}$ molar ratio (from 1 to 2 ) can be easily tuned by adjusting the $\mathrm{SiO}_{2}$-sol content $(0-30 \mathrm{~g})$.

Table 2. Mixture formulations for geopolymer gels with various designated Si/Al molar ratios.

\begin{tabular}{cccc}
\hline $\mathbf{S i} / \mathbf{A l} \mathbf{~ ( \% )}$ & $\mathbf{S i O}_{\mathbf{2}}$-sol $\mathbf{( g )}$ & $\mathbf{N a O H}(\mathbf{g})$ & $\mathbf{M K}(\mathbf{g})$ \\
\hline 1.00 & 0.0 & 8.33 & 22.2 \\
1.25 & 7.5 & 8.33 & 22.2 \\
1.50 & 15.0 & 8.33 & 22.2 \\
1.75 & 22.5 & 8.33 & 22.2 \\
2.00 & 30.0 & 8.33 & 22.2 \\
\hline
\end{tabular}

\subsection{Characterization}

To study the decomposition profile of the mixture before high temperature treatment, differential scanning calorimetry and thermogravimetric analysis (DSC/TGA, STA449C, Netzsch, Selb, Germany) was firstly carried out for the egg yellow mixture powder from room temperature to $1200{ }^{\circ} \mathrm{C}$ with a heating rate of $10{ }^{\circ} \mathrm{C} / \mathrm{min}$ in static air atmosphere.

Phase assemblage was identified, using X-ray diffraction (XRD, Panalytica, the Netherlands) on N-MK and S-MK powder together with samples after hydrothermal treatment with a scan speed of $4^{\circ} / \mathrm{min}$ and an increment of $0.02^{\circ}$. The XRD data were recorded and selected between $5^{\circ}$ and $80^{\circ}$ at room temperature, using $\mathrm{Cu} \mathrm{K} \alpha$ radiation $(\lambda=0.15406 \mathrm{~nm})$ at $40 \mathrm{kV}$ and $10 \mathrm{~mA}$.

The microstructure of the N-MK and S-MK samples as well as samples after hydrothermal treatment were observed by scanning electron microscopy (SEM, Helios NanoLab 600i, FEI, Hillsboro, OR, USA) at $20 \mathrm{kV}$ after gold sputtering. An image analysis software (Nano Measurer 1.2) $[60,61]$ was applied to describe the particle size and grain size, based on the SEM images.

The molecular structure of the samples after hydrothermal treatment was measured by Fourier-transform infrared spectroscopy (FTIR, Nicolet-IS50, Thermo Scientific, Waltham, MA, USA) in the range $450-4000 \mathrm{~cm}^{-1}$ with the $\mathrm{KBr}$ pellet.

\section{Results and Discussion}

\subsection{Characterization of Synthetic Metakaolin}

A DSC-TG analysis (Figure 2) was firstly carried out in air to determine the thermal degradation of the egg-yellow powder. It indicated that the thermal degradation of the organic components in chemosynthetic powder took place over a broad temperature from $100{ }^{\circ} \mathrm{C}$ to $500{ }^{\circ} \mathrm{C}$. Below $250{ }^{\circ} \mathrm{C}$, an endothermic peak at approximately $113^{\circ} \mathrm{C}$ with a mass loss of about $7.0 \mathrm{wt} \%$ was shown, and the weight loss was ascribed to the evaporation of water [10,49]. After that, an exothermic peak was detected, along with approximately $12 \mathrm{wt} \%$ weight loss; the peak was attributed to PVA decomposition [47]. Another strong exothermic peak was observed $\left(\sim 348{ }^{\circ} \mathrm{C}\right)$, caused by the decomposition of $\mathrm{NO}_{3}{ }^{-}$[47]. Simultaneously, approximately $40 \mathrm{wt} \%$ mass loss took place, which was attributed the high amount of $\mathrm{Al}\left(\mathrm{NO}_{3}\right)_{3} \cdot 9 \mathrm{H}_{2} \mathrm{O}$ added for providing the aluminum source [47]. When the sintering temperature increased above $600^{\circ} \mathrm{C}$, the thermogravimetry (TG) curve changed 
gently, while a new exothermic peak at $\sim 914{ }^{\circ} \mathrm{C}$ was shown in the DSC curve, which can be explained by the crystallization [47].

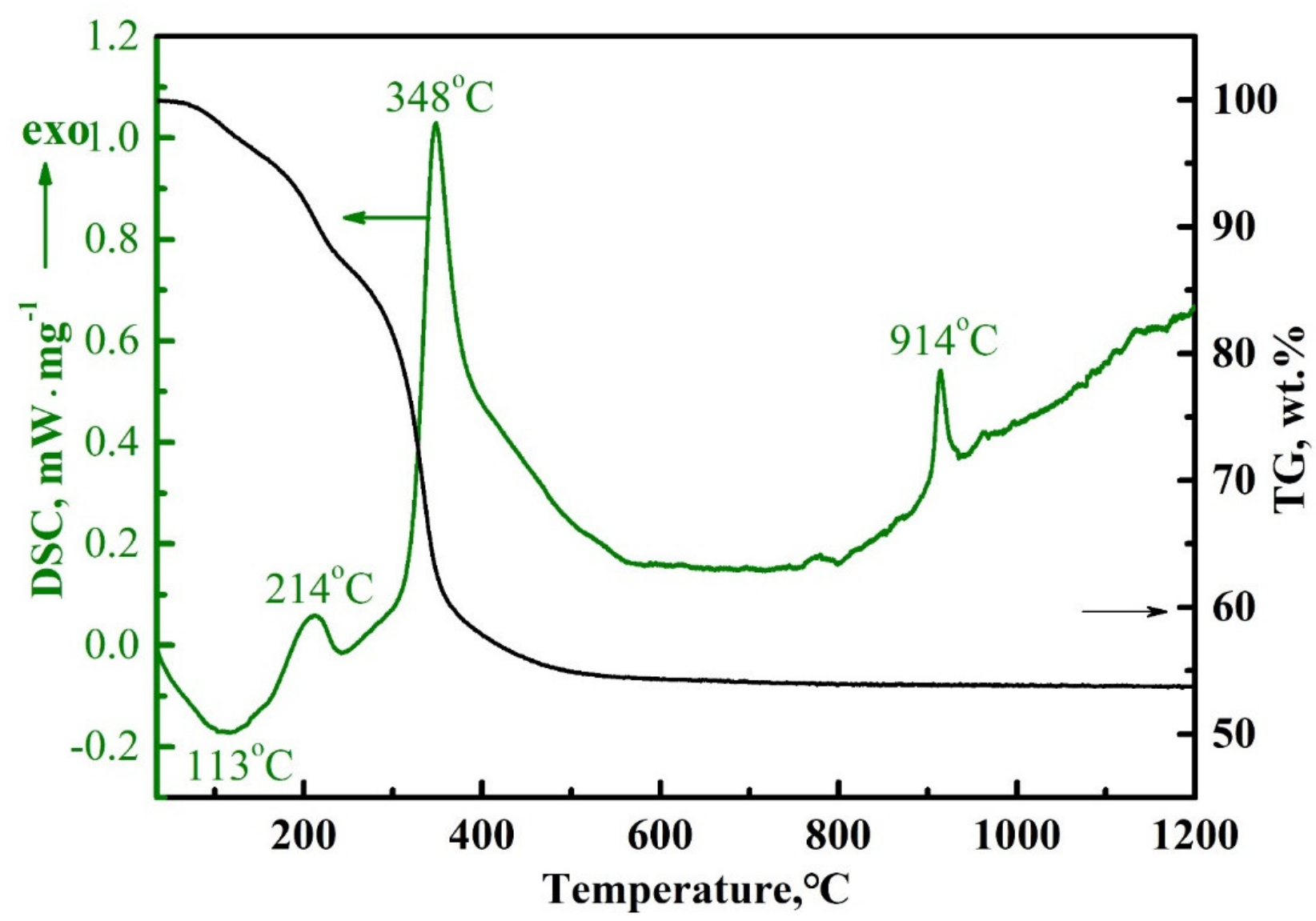

Figure 2. DSC-TGA traces of the synthetic egg-yellow mixture powder.

The XRD patterns of the natural metakaolin (N-MK; Figure 3(a)) and synthetic metakaolin (S-MK; Figure 3(b)) were measured. As can be seen in Figure 3, a typical large broad peak, centered at approximately $22.5^{\circ}(2 \theta)$, was observed both in the N-MK and S-MK $[50,62]$. Unlike the N-MK, only $\mathrm{SiO}_{2}$ and $\mathrm{Al}_{2} \mathrm{O}_{3}$ were detected in S-MK. The XRD data (Figure 3) were consistent with the composition results (Table 1), while only the amorphous $\mathrm{Al}_{2} \mathrm{O}_{3}-\mathrm{SiO}_{2}$ phase is presented in Figure 3(b). As for the N-MK, both $\alpha$-quartz and illite phase were presented [50]. Previous works showed that the quartz almost did not participate in the geopolymer reaction [50,62], and only part of the illite participated in the geopolymerization process [50]. 


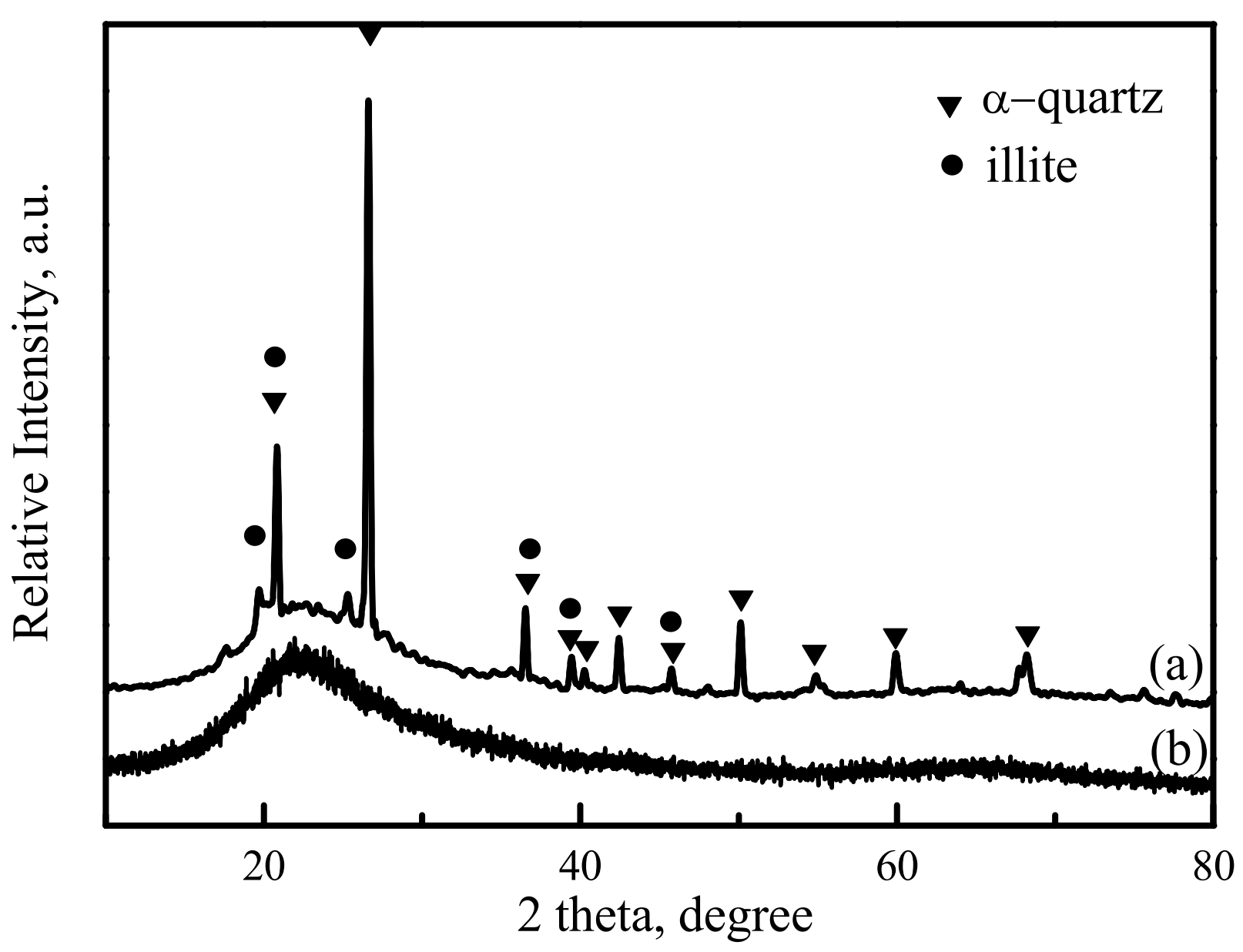

Figure 3. XRD patterns of (a) natural metakaolin (N-MK) and (b) synthetic metakaolin (S-MK).

Figure $4 \mathrm{a}, \mathrm{b}$ demonstrates the microstructure of the N-MK and S-MK samples; the N-MK powder showed laminar and needle-like microstructure and an average size about $10.0 \mu \mathrm{m}$, and the S-MK presented a smaller particle size (about 3.0 $\mathrm{mm}$ ) and a more homogeneous particle size distribution. Particle aggregation was also displayed both in the N-MK and S-MK samples. To further compare the particle size and particle size distribution, the particle size distribution was also investigated and are shown in Figure $4 c, d$, where a rather large size distribution is displayed. The $\mathrm{D}_{50}$ (average particle size) of N-MK and S-MK were $14.2 \mu \mathrm{m}$ and $3.1 \mu \mathrm{m}$; the average particle size data of S-MK was in keeping with the SEM data, while a higher average particle size result was determined by a laser particle analyzer (Horiba, LA-960). The likely explanation was due to the higher degree of agglomerates of N-MK than S-MK. Meanwhile, the particle size data obtained by 2D values were lower than the actual particle size [60]. Comparing with previous works for S-MK by the sol-gel method $[45,63]$, the amorphous X-ray diffraction pattern with a hump centered at approximately $22.5^{\circ}$ was similar, and the $\mathrm{D}_{50}$ data (about $0.5 \mu \mathrm{m}$ ) were smaller than this study, while a more serious agglomeration phenomenon was shown in SEM images by the sol-gel process. In any case, the polymeric steric entrapment precursor route method can be used to effectively obtain pure synthetic metakaolin (amorphous $\mathrm{Al}_{2} \mathrm{O}_{3}-\mathrm{SiO}_{2}$ inorganic materials) with designated chemical compositions. 

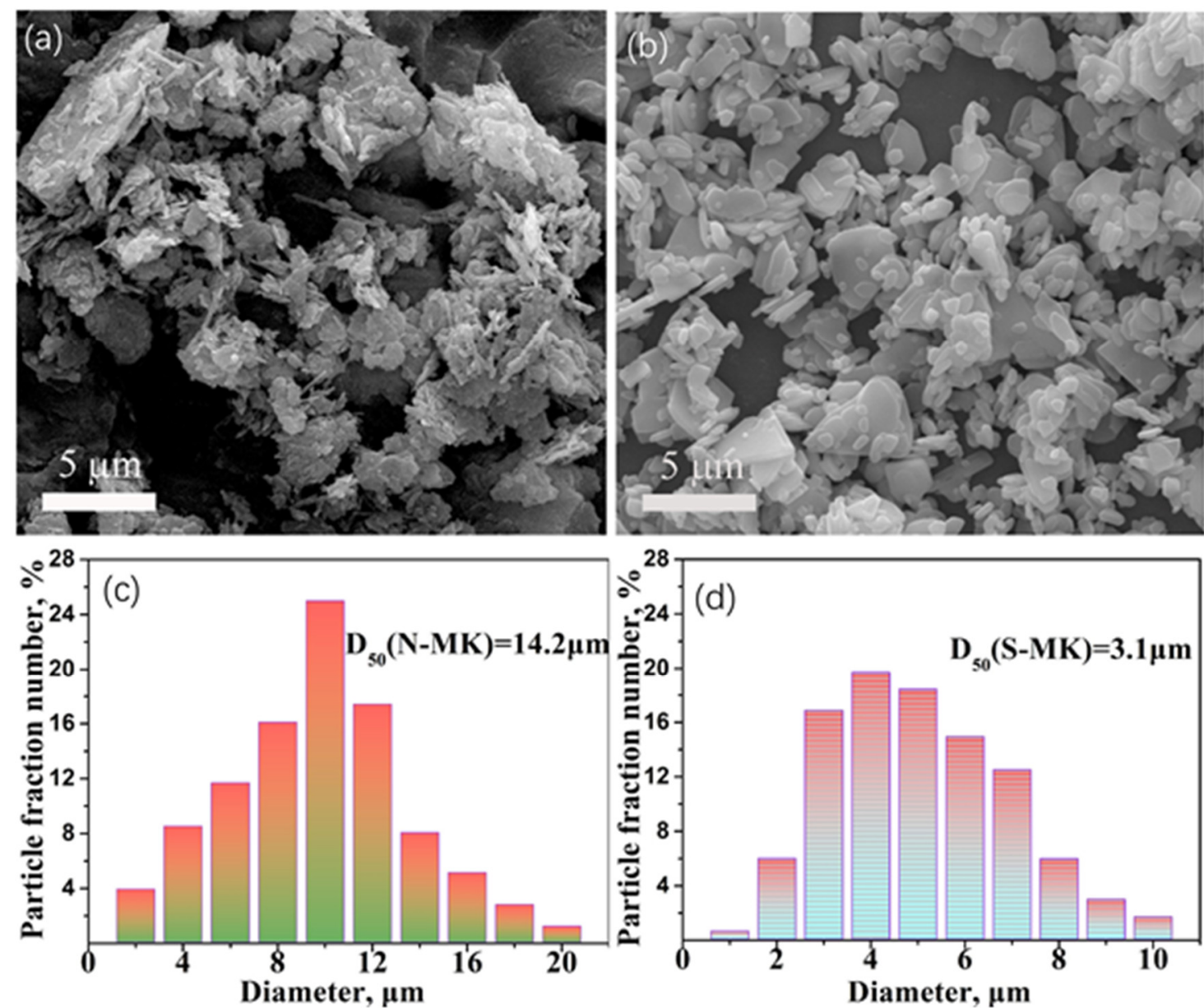

Figure 4. SEM images and particle distributions of (a,c) natural metakaolin (N-MK) and (b,d) synthetic metakaolin (S-MK).

\subsection{Characterization of Zeolite/Geopolymer Composites}

Previous studies indicated that the $\mathrm{Si} / \mathrm{Al}$ ratio or $\mathrm{SiO}_{2} / \mathrm{Al}_{2} \mathrm{O}_{3}$ ratio plays an important role in zeolite formation [50-52]. Firstly, the XRD patterns of samples with different $\mathrm{Si} / \mathrm{Al}$ ratios after hydrothermal treatment are shown in Figure 5. As can be seen, when $\mathrm{Si} / \mathrm{Al}=$ $1.0 \sim 1.25$, the product is mainly NaA-type zeolite, and a higher degree of crystallinity for the zeolite phase is achieved by $\mathrm{Si} / \mathrm{Al}=1.25$. For samples with a low $\mathrm{Si} / \mathrm{Al}$ molar ratio, it can be seen that there is still a small amount of the amorphous phase (geopolymer) in the XRD data, and thus, zeolite/geopolymer composites are formed at a low Si/Al molar ratio; when $\mathrm{Si} / \mathrm{Al}=1.5, \mathrm{NaA}$-type zeolite and the amorphous phase are almost totally disappeared, indicating that almost all the geopolymer precursor is theoretically converted to the zeolite phase, while the analcime phase together with a small amount of sodalite are detected; when $\mathrm{Si} / \mathrm{Al}=1.75$, the phase composition is similar to that of geopolymer with $\mathrm{Si} / \mathrm{Al}=1.5$, and the main phase is analcime with a small amount of sodalite phase as well; furthermore, the crystallinity for the analcime phase increases with the molar ratio from 1.5 to 1.75 ; when $\mathrm{Si} / \mathrm{Al}=2.0$, the crystalline phase is all analcime, however, the crystallinity for analcime phase decreases. 


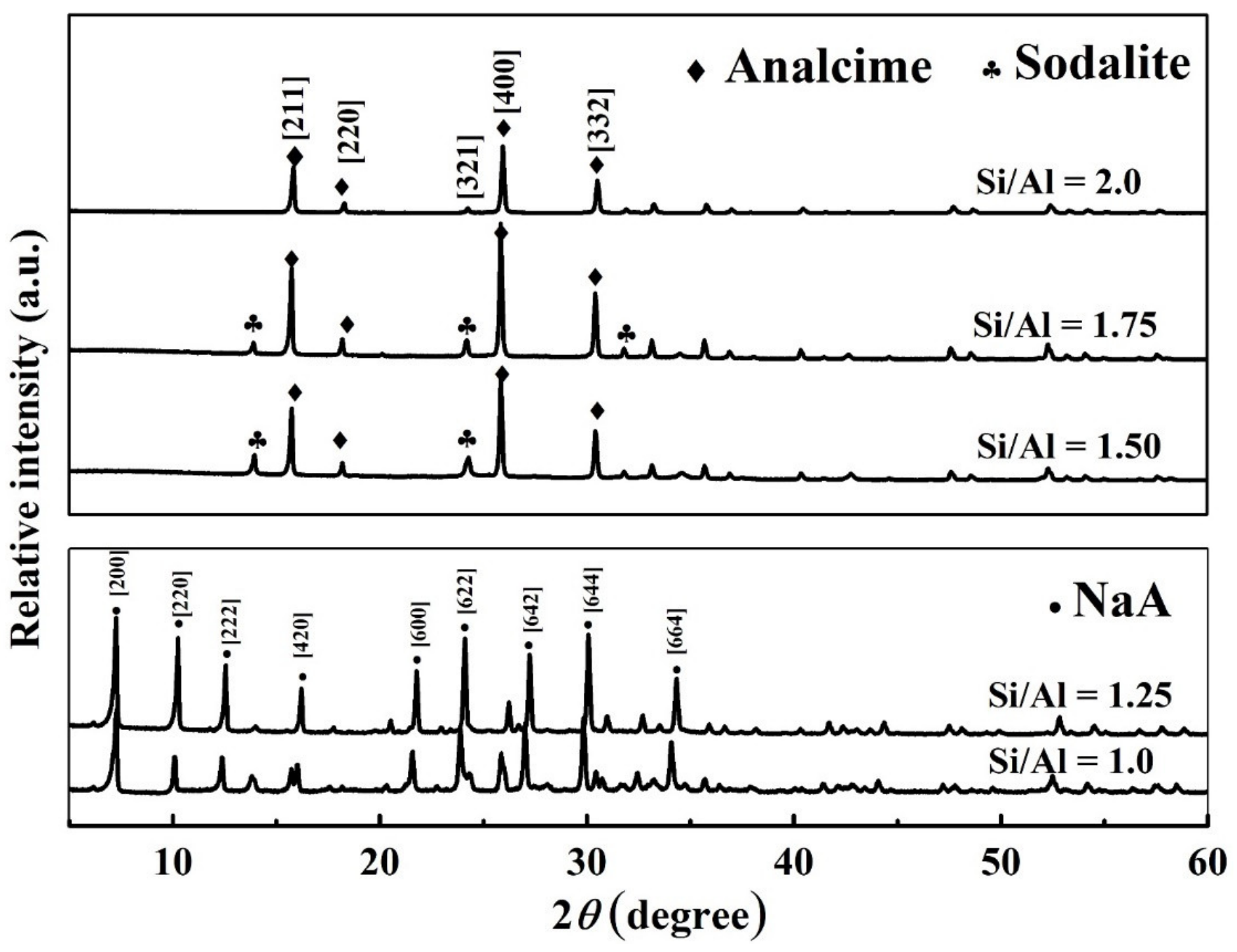

Figure 5. XRD patterns of specimens after hydrothermal treatment with various $\mathrm{Si} / \mathrm{Al}$ molar ratios.

This confirms that both the zeolite phase and the degree of crystallinity for the zeolite phase are determined by the $\mathrm{Si} / \mathrm{Al}$ molar ratio. Similar results are observed for the degree of crystallization of the zeolite phase after hydrothermal treatment [51,52].

Figure 6 shows the microstructure of zeolite/geopolymer composites or zeolite specimens with different $\mathrm{Si} / \mathrm{Al}$ ratios. As shown in Figure 6a, NaA zeolite derived from geopolymer with $\mathrm{Si} / \mathrm{Al}=1$ is composed of regular tetragonal grains with a grain size of about $2 \mu \mathrm{m}$. Combining the XRD data and previous works [45,46,64,65], the regular cubic grains are identified as $\mathrm{NaA}$ zeolite; the structure of the $\mathrm{NaA}$ zeolite was presented in previous works $[66,67]$. When $\mathrm{Si} / \mathrm{Al}=1.25$, except the tetragonal grains of NaA zeolite, there is a small amount of spherical zeolite with an average diameter of $\sim 2 \mu \mathrm{m}$. It can be observed that the small amount of the amorphous phase (geopolymer) is consistent with the XRD results (Figure 5). The polyhedral cubic grains are identified as NaA zeolite; the structure of the NaA zeolite was presented in previous works. 


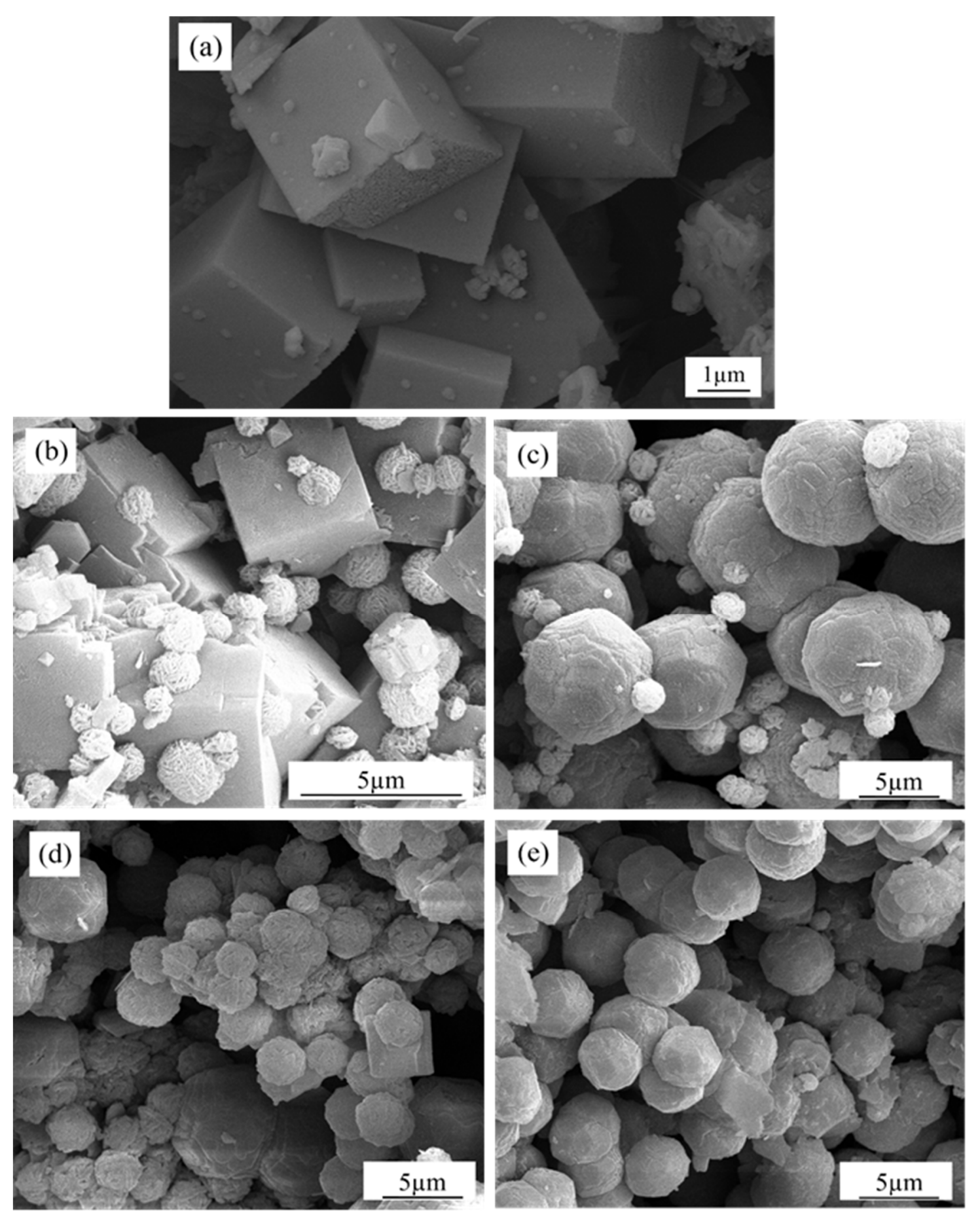

Figure 6. SEM images of specimens after hydrothermal treatment with various $\mathrm{Si} / \mathrm{Al}$ molar ratios. (a) $\mathrm{Si} / \mathrm{Al}=1.0 ;(\mathbf{b}) \mathrm{Si} / \mathrm{Al}$ $=1.25 ;(\mathbf{c}) \mathrm{Si} / \mathrm{Al}=1.50 ;(\mathbf{d}) \mathrm{Si} / \mathrm{Al}=1.75 ;(\mathbf{e}) \mathrm{Si} / \mathrm{Al}=2.0$.

When $\mathrm{Si} / \mathrm{Al}=1.50$, the main phase of the zeolite in NaGP is polyhedral analcime [68-70], with a larger particle size of about $7 \mu \mathrm{m}$; zeolite in the form of "pillared" sodalite can also be noted. When $\mathrm{Si} / \mathrm{Al}=1.75$, both analcime and sodalite crystals can be observed. When $\mathrm{Si} / \mathrm{Al}=2.0$, analcime with a particle size of about $4 \mu \mathrm{m}$ can be observed. The microstructure results are in agreement with the XRD analysis, and the crystal structure of analcime is illustrated as well [69,70]. Furthermore, the designed $\mathrm{Si} / \mathrm{Al}$ ratio and XRD results are consistent with the theoretical chemical formula of $\mathrm{NaA}$ zeolite ( $\mathrm{Na} 96$ 
$\left[\left(\mathrm{AlO}_{2}\right)_{96}\left(\mathrm{SiO}_{2}\right)_{96}\right] \cdot 216 \mathrm{H}_{2} \mathrm{O}$ [44], sodalite $\left(\mathrm{Na}_{6}\left(\mathrm{H}_{2} \mathrm{O}\right)_{8} \mathrm{Si}_{6} \mathrm{Al}_{6} \mathrm{O}_{24} ; \mathrm{Si} / \mathrm{Al}=1\right)$ and analcime $\left(\mathrm{NaAlSi}_{2} \mathrm{O}_{6} \cdot \mathrm{H}_{2} \mathrm{O} ; \mathrm{Si} / \mathrm{Al}=2\right)[18,33]$.

The XRD data combined with the SEM results indicate that zeolite/geopolymer composites and pure zeolite of the monolith type could be prepared from S-MK-based geopolymer through hydrothermal processes. Comparing with previous works using combined hydrothermal treatments and a geopolymer precursor technique with fly ash [51,52] and metakaolin [57-59,71,72] minerals as the starting materials, a higher degree of crystallization with regular crystal edges was obtained by this study.

A FTIR spectrum (Figure 7) of samples with various $\mathrm{Si} / \mathrm{Al}$ molar ratios are studied as well. A strong characteristic band located at approximately $1001 \mathrm{~cm}^{-1}$ for zeolite/geopolymer composites are visible. The strong band in the range from 900 to $1030 \mathrm{~cm}^{-1}$ is linked to the asymmetric $\mathrm{Al}-\mathrm{O} / \mathrm{Si}-\mathrm{O}$ stretching vibration in geopolymer matrix or zeolite [52,73]. Generally, the strong band at about $1000 \mathrm{~cm}^{-1}$ is considered the characteristic band for geopolymer $[60,62,74]$. The bands located at around $558 \mathrm{~cm}^{-1}$ and $460 \mathrm{~cm}^{-1}$ are only detected when $\mathrm{Si} / \mathrm{Al}=1.75$; the two signals are respectively associated with the bending vibration of $\mathrm{Si}-\mathrm{O}-\mathrm{Al}$ and $\mathrm{Al}-\mathrm{O} / \mathrm{Si}-\mathrm{O}$, which were observed in geopolymer [52,75-77]. The possible explanation is that there are still some unreacted geopolymer gels remaining after the hydrothermal treatment. Again, it confirms that the geopolymer exists with a $\mathrm{Si} / \mathrm{Al}$ ratio lower than 1.75, as shown in Figure 7.

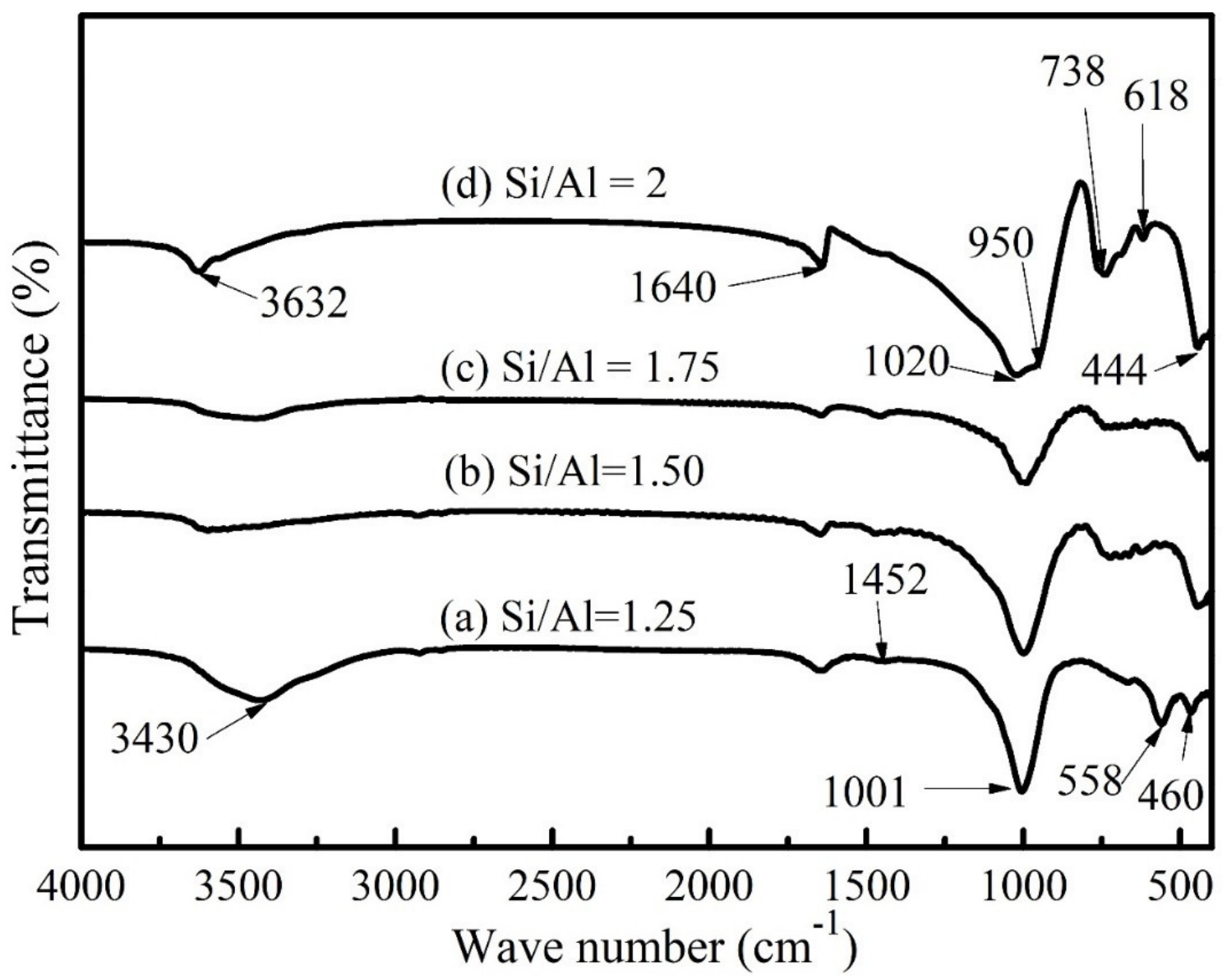

Figure 7. FTIR results of specimens after hydrothermal treatment with various $\mathrm{Si} / \mathrm{Al}$ molar ratios.

A small band located at about $1433-1478 \mathrm{~cm}^{-1}$ is assigned to $\mathrm{CO}_{3}{ }^{2-}(\mathrm{O}-\mathrm{C}-\mathrm{O}$ stretching vibration), due to carbonation or weathering for the alkaline matrix $[52,73,78]$. The signals at $\sim 1640$ and $\sim 3436 \mathrm{~cm}^{-1}$ are respectively ascribed to the stretching and deformation vibrations of $\mathrm{OH}$ and $\mathrm{H}-\mathrm{O}-\mathrm{H}$ groups deriving from the water molecules [52,73]. Previous 
works showed that the wavenumbers at $\sim 444, \sim 738, \sim 1020, \sim 1640$, and $\sim 3620 \mathrm{~cm}^{-1}$ belong to analcime $[79,80]$.

\section{Conclusions}

A polymeric steric entrapment precursor route was used to fabricate synthetic metakaolin; the particle size distribution, chemical and phase composition as well as the microstructure were investigated and compared with natural metakaolin. It showed that amorphous powders (S-MK) with controlled chemical composition $\left(\mathrm{Al}_{2} \mathrm{O}_{3} \cdot x \mathrm{SiO}_{2}\right)$ can be prepared by the simple chemosynthetic route. The obtained S-MK powders $\left(\mathrm{Al}_{2} \mathrm{O}_{3} \cdot 2 \mathrm{SiO}_{2}\right)$ were used to produce a geopolymer precursor for zeolite formation; it indicated that when the molar ratio of $\mathrm{Si} / \mathrm{Al}$ $\leq 1.25$, zeolite/geopolymer composites can be obtained as the existence of geopolymer gels, which was confirmed by XRD, FTIR, and SEM data. Almost all of the geopolymer gels can be transformed into zeolite at a higher molar ratio of $\mathrm{Si} / \mathrm{Al}$. It confirms that the molar ratio of $\mathrm{Si} / \mathrm{Al}$ has a significant effect on the phase transformations and microstructure. NaA zeolite is the main phase when the molar ratio is less than 1.25 , and the main phase is transformed to analcime as the molar ratio increases from 1.5 to 2 . More investigation will be carried out for the obtained monolith-type zeolite/geopolymer composites and pure zeolite, including their porosity, mechanical properties, adsorption properties, etc., in future work.

Author Contributions: Conceptualization and methodology, P.H. and M.W.; formal analysis, G.M. and C.B.; investigation and data curation, G.M. and M.W.; writing-original draft preparation, G.M. and M.W.; writing-review and editing, C.B. and P.H.; supervision, P.H.; project administration and funding acquisition, C.B. and P.H. All authors have read and agreed to the published version of the manuscript.

Funding: This research was funded by Heilongjiang Postdoctoral Science Foundation Funded Project, grant number LBH-Z19051; Heilongjiang Touyan Innovation Team Program; Fundamental Research Funds for the Central Universities, grant number 3072021CF1021; the Scientific Research Foundation for the Returned Overseas Chinese Scholars of Heilongjiang Province, grant number 2019QD0002.

Conflicts of Interest: The authors declare no conflict of interest.

\section{References}

1. Bai, C.; Colombo, P. Processing, properties and applications of highly porous geopolymers: A review. Ceram. Int. 2018, 44, 16103-16118. [CrossRef]

2. Novais, R.M.; Pullar, R.C.; Labrincha, J.A. Geopolymer foams: An overview of recent advancements. Prog. Mater. Sci. 2020, 109, 100621. [CrossRef]

3. Yan, S.; Zhang, F.; Li, H.; Gao, B.; Xing, P.; He, P.; Jia, D. Synthesis and mechanical properties of lightweight hybrid geopolymer foams reinforced with carbon nanotubes. Int. J. Appl. Ceram. Technol. 2020, 17, 1-11. [CrossRef]

4. Zhang, L.; Zhang, F.; Liu, M.; Hu, X. Novel sustainable geopolymer based syntactic foams: An eco-friendly alternative to polymer based syntactic foams. Chem. Eng. J. 2017, 313, 74-82. [CrossRef]

5. Kovářík, T.; Křenek, T.; Rieger, D.; Pola, M.; Říha, J.; Svoboda, M.; Beneš, J.; Šutta, P.; Bělský, P.; Kadlec, J. Synthesis of open-cell ceramic foam derived from geopolymer precursor via replica technique. Mater. Lett. 2017, 209, 497-500. [CrossRef]

6. Medpelli, D.; Seo, J.M.; Seo, D.K. Geopolymer with hierarchically meso-/macroporous structures from reactive emulsion templating. J. Am. Ceram. Soc. 2014, 97, 70-73. [CrossRef]

7. Huang, Y.; Gong, L.; Pan, Y.; Li, C.; Zhou, T.; Cheng, X. Facile construction of the aerogel/geopolymer composite with ultra-low thermal conductivity and high mechanical performance. RSC Adv. 2018, 8, 2350-2356. [CrossRef]

8. Franchin, G.; Pesonen, J.; Luukkonen, T.; Bai, C.; Scanferla, P.; Botti, R.; Carturan, S.; Innocentini, M.; Colombo, P. Removal of ammonium from wastewater with geopolymer sorbents fabricated via additive manufacturing. Mater. Des. 2020, $195,109006$. [CrossRef]

9. Papa, E.; Medri, V.; Natali Murri, A.; Miccio, F.; Landi, E. Ice-Templated Geopolymer-Fe/Mn Oxide Composites Conceived as Oxygen Carriers. Ceramics 2019, 2, 148-160. [CrossRef]

10. Bai, C.; Zheng, J.; Rizzi, G.A.; Colombo, P. Low-temperature fabrication of SiC/geopolymer cellular composites. Compos. Part B Eng. 2018, 137. [CrossRef]

11. Li, F.; Huang, X.; Liu, J.X.; Zhang, G.J. Sol-gel derived porous ultra-high temperature ceramics. J. Adv. Ceram. 2020, 9, 1-16. [CrossRef]

12. Wang, L.; An, L.; Zhao, J.; Shimai, S.; Mao, X.; Zhang, J.; Liu, J.; Wang, S. High-strength porous alumina ceramics prepared from stable wet foams. J. Adv. Ceram. 2021, 10, 852-859. [CrossRef] 
13. Qiao, Y.; Yao, Z.; Wang, X.; Zhang, X.; Bai, C.; Li, Q.; Chen, K.; Li, Z.; Zheng, T. Lattice composites with embedded short carbon fiber/Fe3O4/epoxy hollow spheres for structural performance and microwave absorption. Mater. Des. 2020, $188,108427$. [CrossRef]

14. Xing, Z.; Ke, H.; Wang, X.; Zheng, T.; Qiao, Y.; Chen, K.; Zhang, X.; Zhang, L.; Bai, C.; Li, Z. Investigation of the thermal conductivity of resin-based lightweight composites filled with hollow glass microspheres. Polymers 2020, 12, 518. [CrossRef]

15. Banhart, J. Manufacture, characterisation and application of cellular metals and metal foams. Prog. Mater. Sci. 2001, 46, 559-632. [CrossRef]

16. Nasir, S.; Hung, K.; Poh, S.; Yang, J.; Ling, T. Lightweight foamed concrete as a promising avenue for incorporating waste materials: A review. Resour. Conserv. Recycl. 2021, 164, 105103. [CrossRef]

17. Zhang, X.; Bai, C.; Qiao, Y.; Wang, X.; Jia, D.; Li, H.; Colombo, P. Porous geopolymer composites: A review. Compos. Part A Appl. Sci. Manuf. 2021, 150, 106629. [CrossRef]

18. Rożek, P.; Król, M.; Mozgawa, W. Geopolymer-zeolite composites: A review. J. Clean. Prod. 2019, 230, 557-579. [CrossRef]

19. Anshul, A.; Moinuddin, A.A.; Azad, A.M.; Khera, P.; Dehariya, K.; Bherwani, H.; Gupta, A.; Kumar, S. Morphologically designed micro porous zeolite-geopolymers as cool coating materials. J. Hazard. Mater. 2020, 398, 123022. [CrossRef] [PubMed]

20. Minelli, M.; Papa, E.; Medri, V.; Miccio, F.; Benito, P.; Doghieri, F.; Landi, E. Characterization of novel geopolymer-Zeolite composites as solid adsorbents for $\mathrm{CO}_{2}$ capture. Chem. Eng. J. 2018, 341, 505-515. [CrossRef]

21. Liu, Y.; Yan, C.; Zhang, Z.; Li, L.; Wang, H.; Pu, S. One-step fabrication of novel porous and permeable self-supporting zeolite block from fly ash. Mater. Lett. 2017, 196, 328-331. [CrossRef]

22. Zheng, Z.; Ma, X.; Zhang, Z.; Li, Y. In-situ transition of amorphous gels to Na-P1 zeolite in geopolymer: Mechanical and adsorption properties. Constr. Build. Mater. 2019, 202, 851-860. [CrossRef]

23. He, P.; Wang, Q.; Fu, S.; Wang, M.; Zhao, S.; Liu, X.; Jiang, Y.; Jia, D.; Zhou, Y. Hydrothermal transformation of geopolymers to bulk zeolite structures for efficient hazardous elements adsorption. Sci. Total Environ. 2021, 767, 144973. [CrossRef]

24. He, P.Y.; Zhang, Y.J.; Chen, H.; Han, Z.C.; Liu, L.C. Low-cost and facile synthesis of geopolymer-zeolite composite membrane for chromium(VI) separation from aqueous solution. J. Hazard. Mater. 2020, 392, 122359. [CrossRef]

25. Chen, L.H.; Li, X.Y.; Rooke, J.C.; Zhang, Y.H.; Yang, X.Y.; Tang, Y.; Xiao, F.S.; Su, B.L. Hierarchically structured zeolites: Synthesis, mass transport properties and applications. J. Mater. Chem. 2012, 22, 17381-17403. [CrossRef]

26. Dong, M. Strategies to control zeolite particle morphology. Chem. Soc. Rev. 2019, 48, 885-907. [CrossRef]

27. Moliner, M.; Martínez, C.; Corma, A. Multipore zeolites: Synthesis and catalytic applications. Angew. Chem. Int. Ed. 2015, 54, 3560-3579. [CrossRef] [PubMed]

28. Jiang, N.; Shang, R.; Heijman, S.G.J.; Rietveld, L.C. High-silica zeolites for adsorption of organic micro-pollutants in water treatment: A review. Water Res. 2018, 144, 145-161. [CrossRef]

29. Ide, Y.; Tominaka, S.; Kono, H.; Ram, R.; Machida, A.; Tsunoji, N. Zeolitic intralayer microchannels of magadiite, a natural layered silicate, to boost green organic synthesis. Chem. Sci. 2018, 9, 8637-8643. [CrossRef]

30. Cataldo, E.; Salvi, L.; Paoli, F.; Fucile, M.; Masciandaro, G.; Manzi, D.; Masini, C.M.; Mattii, G.B. Application of zeolites in agriculture and other potential uses: A review. Agronomy 2021, 11, 1547. [CrossRef]

31. Mahesh, M.; Thomas, J.; Arun Kumar, K.; Bhople, B.S.; Saresh, N.V.; Vaid, S.K.; Sahu, S.K. Zeolite Farming: A Sustainable Agricultural Prospective. Int. J. Curr. Microbiol. Appl. Sci. 2018, 7, 2912-2924. [CrossRef]

32. De Bruijn, J.; Gómez, A.; Loyola, C.; Melín, P.; Solar, V.; Abreu, N.; Azzolina-Jury, F.; Valdés, H. Use of a copper-and zinc-modified natural zeolite to improve ethylene removal and postharvest quality of tomato fruit. Crystals 2020, 10, 471. [CrossRef]

33. Harja, M.; Cimpeanu, S.M.; Dirja, M.; Bucur, D. Synthesis of Zeolite from Fly Ash and their Use as Soil Amendment. In Zeolites Useful Minerals; Belviso, C., Ed.; IntechOpen: Rijeka, Croatia, 2016.

34. Nikolov, A.; Rostovsky, I.; Nugteren, H. Geopolymer materials based on natural zeolite. Case Stud. Constr. Mater. 2017, 6, 198-205. [CrossRef]

35. Rangnekar, N.; Mittal, N.; Elyassi, B.; Caro, J.; Tsapatsis, M. Zeolite membranes-A review and comparison with MOFs. Chem. Soc. Rev. 2015, 44, 7128-7154. [CrossRef] [PubMed]

36. Li, Y.; Yang, W. Microwave synthesis of zeolite membranes: A review. J. Memb. Sci. 2008, 316, 3-17. [CrossRef]

37. Dusselier, M.; Davis, M.E. Small-Pore Zeolites: Synthesis and Catalysis. Chem. Rev. 2018, 118, 5265-5329. [CrossRef]

38. Verboekend, D.; Nuttens, N.; Locus, R.; Van Aelst, J.; Verolme, P.; Groen, J.C.; Pérez-Ramírez, J.; Sels, B.F. Synthesis, characterisation, and catalytic evaluation of hierarchical faujasite zeolites: Milestones, challenges, and future directions. Chem. Soc. Rev. 2016, 45, 3331-3352. [CrossRef]

39. Doustkhah, E.; Mohtasham, H.; Hasani, M.; Ide, Y.; Rostamnia, S.; Tsunoji, N.; Hussein, M. Merging periodic mesoporous organosilica (PMO) with mesoporous aluminosilica (Al/Si-PMO): A catalyst for green oxidation. Mol. Catal. 2020, $482,110676$. [CrossRef]

40. Collins, F.; Rozhkovskaya, A.; Outram, J.G.; Millar, G.J. A critical review of waste resources, synthesis, and applications for Zeolite LTA. Microporous Mesoporous Mater. 2020, 291, 109667. [CrossRef]

41. Król, M. Natural vs. Synthetic zeolites. Crystals 2020, 10, 622. [CrossRef]

42. Wang, C.; Xu, G.; Gu, X.; Gao, Y.; Zhao, P. High value-added applications of coal fly ash in the form of porous materials: A review. Ceram. Int. 2021, 47, 22302-22315. [CrossRef] 
43. Feng, C.; Zhang, K.; He, R.; Ding, G.; Xia, M.; Jin, X.; Xie, C. Additive manufacturing of hydroxyapatite bioceramic scaffolds: Dispersion, digital light processing, sintering, mechanical properties, and biocompatibility. J. Adv. Ceram. 2020, 9, 360-373. [CrossRef]

44. Xuemin, C.; Yan, H.; Leping, L.; Jinyu, C. NaA zeolite synthesis from geopolymer precursor. MRS Commun. 2011, 1, 49-51. [CrossRef]

45. Yan, H.; Xue-Min, C.; Jin, M.; Liu, L.P.; Liu, X.D.; Chen, J.Y. The hydrothermal transformation of solid geopolymers into zeolites. Microporous Mesoporous Mater. 2012, 161, 187-192. [CrossRef]

46. He, Y.; Cui, X.M.; Liu, X.D.; Wang, Y.P.; Zhang, J.; Liu, K. Preparation of self-supporting NaA zeolite membranes using geopolymers. J. Memb. Sci. 2013, 447, 66-72. [CrossRef]

47. Nguyen, M.H.; Lee, S.J.; Kriven, W.M. Synthesis of oxide powders by way of a polymeric steric entrapment precursor route. J. Mater. Res. 1999, 14, 3417-3426. [CrossRef]

48. Gordon, M.; Bell, J.L.; Kriven, W.M. Comparison of Naturally and Synthetically-Derived, Potassium-Based Geopolymers. In Advances in Ceramic Matrix Composites X; Singh, J.P., Bansal, N.P., Kriven, W.M., Eds.; The American Ceramic Society: Westerville, OH, USA, 2005; ISBN 1-57498-186-2.

49. He, P.; Jia, D. Low-temperature sintered pollucite ceramic from geopolymer precursor using synthetic metakaolin. J. Mater. Sci. 2013, 48, 1812-1818. [CrossRef]

50. Zibouche, F.; Kerdjoudj, H.; Espinose, J.; Lacaillerie, D.; Damme, H. Van Geopolymers from Algerian metakaolin. Influence of secondary minerals. Appl. Clay Sci. 2009, 43, 453-458. [CrossRef]

51. Qiu, X.; Liu, Y.; Li, D.; Yan, C. Preparation of NaP zeolite block from fly ash-based geopolymer via in situ hydrothermal method. J. Porous Mater. 2014, 22, 291-299. [CrossRef]

52. Liu, Y.; Yan, C.; Qiu, X.; Li, D.; Wang, H.; Alshameri, A. Preparation of faujasite block from fly ash-based geopolymer via in-situ hydrothermal method. Rev. Mex. Urol. 2016, 76, 433-439. [CrossRef]

53. Lee, N.K.; Khalid, H.R.; Lee, H.K. Synthesis of mesoporous geopolymers containing zeolite phases by a hydrothermal treatment. Microporous Mesoporous Mater. 2016, 229, 22-30. [CrossRef]

54. Khalid, H.R.; Lee, N.K.; Choudhry, I.; Wang, Z.; Lee, H.K. Evolution of zeolite crystals in geopolymer-supported zeolites: Effects of composition of starting materials. Mater. Lett. 2019, 239, 33-36. [CrossRef]

55. Abdullahi, T.; Harun, Z.; Hafiz, M.; Othman, D. A review on sustainable synthesis of zeolite from kaolinite resources via hydrothermal process. Adv. Powder Technol. 2017, 28, 1827-1840. [CrossRef]

56. Ge, Y.; Yuan, Y.; Wang, K.; He, Y.; Cui, X. Preparation of geopolymer-based inorganic membrane for removing $\mathrm{Ni}^{2+}$ from wastewater. J. Hazard. Mater. 2015, 299, 711-718. [CrossRef]

57. Wang, H.; Yan, C.; Li, D.; Zhou, F.; Liu, Y.; Zhou, C.; Komarneni, S. In situ transformation of geopolymer gels to self-supporting NaX zeolite monoliths with excellent compressive strength. Microporous Mesoporous Mater. 2018, 261, 164-169. [CrossRef]

58. Tang, Q.; He, Y.; Wang, Y.P.; Wang, K.T.; Cui, X.M. Study on synthesis and characterization of ZSM-20 zeolites from metakaolinbased geopolymers. Appl. Clay Sci. 2016, 129, 102-107. [CrossRef]

59. Zhang, J.; He, Y.; Wang, Y.P.; Mao, J.; Cui, X.M. Synthesis of a self-Supporting faujasite zeolite membrane using geopolymer gel for separation of alcohol/water mixture. Mater. Lett. 2014, 116, 167-170. [CrossRef]

60. Qiao, Y.; Li, X.; Bai, C.; Li, H.; Yan, J.; Wang, Y.Y.; Wang, X.; Zhang, X.; Zheng, T.; Colombo, P. Effects of surfactants/stabilizing agents on the microstructure and properties of porous geopolymers by direct foaming. J. Asian Ceram. Soc. 2021, 9, 412-423. [CrossRef]

61. Li, W.; Hao, J.; Li, W.; Du, J.; Fu, P.; Sun, W.; Chen, C.; Xu, Z.; Chu, R. Electrical properties and luminescence properties of $0.96(\mathrm{~K} 0.48 \mathrm{Na} 0.52)(\mathrm{Nb} 0.95 \mathrm{Sb} 0.05)-0.04 \mathrm{Bi} 0.5(\mathrm{Na} 0.82 \mathrm{~K} 0.18) 0.5 \mathrm{ZrO}-\mathrm{xSm}$ lead-free ceramics. J. Adv. Ceram. 2020, 9, 72-82. [CrossRef]

62. Bai, C.; Li, H.; Bernardo, E.; Colombo, P. Waste-to-resource preparation of glass-containing foams from geopolymers. Ceram. Int. 2019, 45, 7196-7202. [CrossRef]

63. Cui, X.M.; Zheng, G.J.; Han, Y.C.; Su, F.; Zhou, J. A study on electrical conductivity of chemosynthetic $\mathrm{Al}_{2} \mathrm{O}_{3}-2 \mathrm{SiO}_{2}$ geopolymer materials. J. Power Sources 2008, 184, 652-656. [CrossRef]

64. Qian, T.; Li, J. Synthesis of Na-A zeolite from coal gangue with the in-situ crystallization technique. Adv. Powder Technol. 2015, 26, 98-104. [CrossRef]

65. Li, Y.; Peng, T.; Man, W.; Ju, L.; Zheng, F.; Zhang, M.; Guo, M. Hydrothermal synthesis of mixtures of NaA zeolite and sodalite from Ti-bearing electric arc furnace slag. RSC Adv. 2016, 6, 8358-8366. [CrossRef]

66. Liu, Q.; MacE, A.; Bacsik, Z.; Sun, J.; Laaksonen, A.; Hedin, N. NaKA sorbents with high $\mathrm{CO}_{2}$-over- $\mathrm{N}_{2}$ selectivity and high capacity to adsorb $\mathrm{CO}_{2}$. Chem. Commun. 2010, 46, 4502-4504. [CrossRef] [PubMed]

67. Yoshida, K.; Toyoura, K.; Matsunaga, K.; Nakahira, A.; Kurata, H.; Ikuhara, Y.H.; Sasaki, Y. Atomic sites and stability of Cs ${ }^{+}$ captured within zeolitic nanocavities. Sci. Rep. 2013, 3. [CrossRef] [PubMed]

68. Yuan, J.; Yang, J.; Ma, H.; Liu, C. Crystal structural transformation and kinetics of $\mathrm{NH}_{4}^{+} / \mathrm{Na}^{+}$ion-exchange in analcime. Microporous Mesoporous Mater. 2016, 222, 202-208. [CrossRef]

69. Shao, N.; Tang, S.; Li, S.; Chen, H.; Zhang, Z. Defective analcime/geopolymer composite membrane derived from fly ash for ultrafast and highly efficient filtration of organic pollutants. J. Hazard. Mater. 2020, 388, 121736. [CrossRef] 
70. Ge, Y.Y.; Tang, Q.; Cui, X.M.; He, Y.; Zhang, J. Preparation of large-sized analcime single crystals using the Geopolymer-GelsConversion (GGC) method. Mater. Lett. 2014, 135, 15-18. [CrossRef]

71. Koloušek, D.; Brus, J.; Urbanova, M.; Andertova, J.; Hulinsky, V.; Vorel, J. Preparation, structure and hydrothermal stability of alternative (sodium silicate-free) geopolymers. J. Mater. Sci. 2007, 42, 9267-9275. [CrossRef]

72. Zhang, Y.J.; Chen, H.; He, P.Y.; Li, C.J. Developing silica fume-based self-supported ECR-1 zeolite membrane for seawater desalination. Mater. Lett. 2019, 236, 538-541. [CrossRef]

73. Ma, X.; Zhang, Z.; Wang, A. The transition of fly ash-based geopolymer gels into ordered structures and the effect on the compressive strength. Constr. Build. Mater. 2016, 104, 25-33. [CrossRef]

74. Tchakouté, H.K.; Rüscher, C.H.; Hinsch, M.; Djobo, J.N.Y.; Kamseu, E.; Leonelli, C. Utilization of sodium waterglass from sugar cane bagasse ash as a new alternative hardener for producing metakaolin-based geopolymer cement. Chem. Erde 2017, 77, 257-266. [CrossRef]

75. Liu, Y.; Yan, C.; Zhang, Z.; Gong, Y.; Wang, H.; Qiu, X. A facile method for preparation of floatable and permeable fly ash-based geopolymer block. Mater. Lett. 2016, 185, 370-373. [CrossRef]

76. Tchakouté, H.K.; Rüscher, C.H.; Kong, S.; Kamseu, E.; Leonelli, C. Thermal Behavior of Metakaolin-Based Geopolymer Cements Using Sodium Waterglass from Rice Husk Ash and Waste Glass as Alternative Activators. Waste Biomass Valorization 2017, 8 , 573-584. [CrossRef]

77. Ge, Y.; Cui, X.; Kong, Y.; Li, Z.; He, Y.; Zhou, Q. Porous geopolymeric spheres for removal of Cu(II) from aqueous solution: Synthesis and evaluation. J. Hazard. Mater. 2015, 283, 244-251. [CrossRef]

78. Puertas, F. Cement and Concrete Research Use of glass waste as an activator in the preparation of alkali-activated slag. Mechanical strength and paste characterisation. Cem. Concr. Res. 2014, 57, 95-104. [CrossRef]

79. Markovic, S.; Dondur, V.; Dimitrijevic, R. FTIR spectroscopy of framework aluminosilicate structures: Carnegieite and pure sodium nepheline. J. Mol. Struct. 2003, 654, 223-234. [CrossRef]

80. Yuan, J.; Yang, J.; Ma, H.; Liu, C.; Zhao, C. Hydrothermal synthesis of analcime and hydroxycancrinite from K-feldspar in $\mathrm{Na}_{2} \mathrm{SiO}_{3}$ solution: Characterization and reaction mechanism. RSC Adv. 2016, 6, 54503-54509. [CrossRef] 